\title{
Ser81 Survivin Induced Protein Kinase A (PKA)-dependent Phosphatidylinositol 3-kinase (PI3K) Activity
}

\author{
Ferry Sandra ${ }^{1,2,3,4, *}$, Roya Khosravi-Far ${ }^{4}$ \\ ${ }^{1}$ Department of Biochemistry and Molecular Biology, Faculty of Dentistry, Trisakti University, Jl. Kyai Tapa No.260, Jakarta, Indonesia \\ ${ }^{2}$ BioCORE Laboratory, Faculty of Dentistry, Trisakti University, Jl. Kyai Tapa No.260, Jakarta, Indonesia \\ ${ }^{3}$ Prodia Clinical Laboratory, Prodia Tower, J1. Kramat Raya No.150, Jakarta, Indonesia \\ ${ }^{4}$ Department of Pathology, Harvard Medical School, BIDMC, Research North, 99 Brookline Ave., Boston, MA 02215, USA \\ ${ }^{*}$ Corresponding author. E-mail: ferrysandra@gmail.com
}

\section{Abstract}

B ACKGROUND: Our previous report showed that phosphorylated-survivin at Ser81 induces survivin back loop to activate protein kinase A (PKA) in the cytoprotection mechanism. Activated PKA could possibly induce the cytoprotection via Phosphatydilinositol 3-kinase (PI3K). Therefore our current study was conducted to investigate the possibility of survivin-PKA-PI3K signaling pathway.

METHODS: Viral productions by BOSC23 cells of Survivin, Antisense Survivin (Survivin-AS) and Ser81Ala mutant (Survivin-S81A) in pMSCV-IRES-GFP vector with cytomegalovirus (CMV) promoter were conducted. L929 cells were pretreated with/without PKI 6-22 amide and infected with viral particle of Survivin, Survivin-AS, Survivin-S81A or vector only. Cells were harvested, lysed and immunoprecipitated with anti-PI3K (p85) antibody and immunoblotted to detect PI3K (p85) and phospho-(Tyr) p85 PI3K. To confirm PI3K activation, PI3K Activity Assay was conducted by using phosphoinositide fraction containing $\operatorname{PtdIns}(4,5) \mathrm{P}_{2}$ and $\left[{ }^{32} \mathrm{P}\right] \mathrm{ATP}$.

RESULTS: Immunoblot and PI3K activity results showed similar results. Upon infection of virus with survivin, a markedly increased level of tyrosine phosphorylation of p85 PI3K or PI3K activity in L929 cells was seen. Low levels of tyrosine phosphorylation of p85 PI3K or PI3K activity were observed for Survivin-AS and Survivin-S81Aviral-infected L929 cells. With higher concentrations of Survivin-viral-infection, levels of tyrosine phosphorylation of p85 PI3K or PI3K activity in L929 cells were gradually

\begin{abstract}
Abstrak

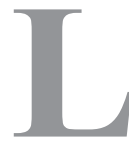

ATAR BELAKANG: Penelitian kami sebelumnya memperlihatkan bahwa survivin yang terfosforilasi pada Ser81, dapat menginduksi survivin back loop sehingga mengaktifkan protein kinase $A$ (PKA) dalam mekanisme pertahanan sel. PKA yang teraktivasi dapat menginduksi pertahanan sel lewat Phosphatydilinositol 3-kinase (PI3K). Oleh karena itu, kami melakukan penelitian ini untuk mengetahui kemungkinan adanya jalur pensinyalan survivin-PKA-PI3K.
\end{abstract}

METODE: Dilakukan produksi virus Survivin, Antisense Survivin (Survivin-AS) dan Ser81Ala mutant (SurvivinS81A) pada plasmid $p M S C V$-IRES-GFP dengan promoter cytomegalovirus (CMV) oleh sel BOSC23. Sel L929 diberikan perlakuan dengan/tanpa PKI 6-22 amide sebelum diinfeksikan dengan virus Survivin, Survivin-AS, SurvivinS81A atau vektor saja. Sel kemudian dikumpulkan, dilisis, dan di-imunopresipitasi dengan antibodi anti-PI3K (p85) dan di-imunoblot untuk mendeteksi PI3K (p85) and phospho(Tyr) p85 PI3K. Untuk mengkonfirmasi adanya aktivasi PI3K, tes aktivitas PI3K dilakukan dengan menggunakan fraksi fosfoinositida dan PtdIns $(4,5) P_{2}$ dan $\left[{ }^{32} P\right] A T P$.

HASIL: Hasil imunoblot dan aktivitas PI3K memperlihatkan hasil yang serupa. Setelah infeksi dengan virus Survivin, terlihat peningkatan level p85 PI3K yang terfosforilasi pada tirosin. Peningkatan aktivitas PI3K juga terlihat. Didapatkan level yang rendah pada p85 PI3K yang terfosforilasi pada tirosin dan aktivitas PI3K pada infeksi virus Survivin-AS dan Survivin-S81A. Dengan konsentrasi virus Survivin yang semakin tinggi, maka level p85 PI3K 
increased. However, when L929 cells were pretreated with PKI 6-22 amide, prior to Survivin-viral-infection, level of tyrosine phosphorylation level of p 85 PI3K or PI3K activity was detected much lower.

CONCLUSION: Our result suggest that Ser81 Survivin play role in inducing PI3K activation and the Survivin-PI3K signaling pathway was PKA-dependent.

KEYWORDS: Ser81, Survivin, PKA, PI3K, L929

Indones Biomed J. 2014; 6(3): 157-62 yang terfosforilasi pada tirosin dan aktivitas PI3K semakin meningkat pula. Akan tetapi, ketika sel L929 diberikan perlakuan dengan PKI 6-22 amide, sebelum infeksi dengan Survivin, level p85 PI3K yang terfosforilasi pada tirosin dan aktivitas PI3K akan rendah sekali.

KESIMPULAN: Ser81 Survivin sangat penting dalam mengiduksi aktivasi PI3K dan jalur pensinyalan SurvivinPI3K merupakan jalur yang bergantung pada PKA.

KATA KUNCI: Ser81, Survivin, PKA, PI3K, L929

\section{Introduction}

Among Inhibitor of mammalian Inhibitor of Apoptosis Proteins (IAPs) family, survivin is the smallest member, containing a single Baculovirus IAP Repeat (BIR), which is the hallmark of these molecules. $(1,2)$ Transcription of the survivin gene is strictly cell cycle-regulated, and peaks at mitosis. $(1,3)$ Survivin plays several roles in homeostatic networks, including the control of mitosis, the regulation of apoptosis and the cellular stress response.(1) Therefore, the presence of survivin in cancer has been linked to resistance to apoptosis, metastasis, cell cycle checkpoints bypass and resistance to therapy. In addition, in some cancers, survivin have identified survivin as a 'risk factor' for poor prognosis and disease recurrence. $(1,4)$

In response to cell death stimulation, survivin physically complexes with X-linked IAP (XIAP), then in turn promotes XIAP stability and synergistic inhibition of caspase-9 activation. $(1,5)$ Besides that, Phosphatydilinositol 3-kinase (PI3K), Akt, $\beta$-catenin, T-cell factor (Tcf), Lymphoid enhancer-binding factor (Lef) and many others implicated in the expression of survivin.(6-8) Our previous report showed that Survivin dominant negative enhanced Tumor necrosis factor (TNF)-related apoptosis-inducing ligand (TRAIL)'s activity in inducing apoptosis.(7) In accordance, a recent report showed a posititve feedback loop connecting survivin expression in tumor cells to PI3K/ Akt, followed by secretion of Vascular Endothelial Growth Factor (VEGF) and angiogenesis.(6)

Amino acid residue Thr34 that lies within sur $\neg$ vivin BIR domain, was shown as an important amino acid in regulation of apoptosis.(9) Phosphorylated-survivin at Thr34 bound to caspase-9 in HeLa cells.(9) In addition, initiated from Scansite result, Ser81 was shown as another potential target to inhibit survivin-modulated cytoprotection as well as to sensitize efficacy of TRAIL or other related apoptotic inducers.(7) Phosphorylated-survivin at Ser81 was later known mediating survivin back loop to activate protein kinase A (PKA) in the cytoprotection mechanism. (10)

As being reported, phosphodiesterase 4 (PDE4) control intracellular cyclic adenosine monophosphate (cAMP) levels by catalyzing their hydrolysis and inactivating second messengers.(11) PDE4 inhibition promotes PKA-dependent resolution of established neutrophilic inflammation by inhibition of the PI3K/Akt/myeloid cell leukemia 1 (Mcl-1) pathway.(11) Due to our previous study in PKA-activation upon phosphorylation of survivin at Ser81 (10), we assume that the activated PKA could possibly induce cytoprotection via PI3K. Therefore our current study was conduced to investigate the possibility of suvivin-PKA-PI3K signaling pathway.

\section{Methods}

\section{Preparation of Survivin Constructs, Viral Production and L929 Cells Infection}

All preparations of Antisense survivin (Survivin-AS) and Ser81Ala mutants (Survivin-S81A) were described in our previous report $(7,10)$. Similar protocols were conducted. Briefly, Survivin, Survivin-AS, Ser81Ala mutants (Survivin-S81A) cDNAs were inserted in pMSCV-IRESGFP vector with cytomegalovirus (CMV) promoter. Each vector was transformed in DH5 $\alpha$ Escherichia coli, purified and confirmed. Each cDNA was transfected in BOSC23 cells by calcium phosphate method with additon of $\mathrm{pCl} 3$ EcotR for 10 hours at $37^{\circ} \mathrm{C}$. Viruses were harvested at 72 hours after transfection and tittered using NIH3T3 cells. 
L929 cells were cultured in $\alpha$-DMEM containing $10 \%$ horse serum. Infection was carried out using viral product of BOSC23 cells (Survivin, Survivin-AS, Survivin-S81A or vector only) for 48 hours.

\section{Cell Treatment, Lysate Preparation and PI3K (p85) Immunoprecipitation}

L929 cells were pretreated with/without $4 \mu \mathrm{M}$ PKI 6-22 amide, a PKA inhibitor (Santa Cruz Biotechnology, Dallas, TX) and infected with viral particle of Survivin, Survivin-AS, Survivin-S81A or vector only. Cells were then harvested and lysed in a cold lysis buffer $(20 \mathrm{mM}$ Tris$\mathrm{HCl}$ buffer $\mathrm{pH}$ 8.0, $500 \mathrm{mM} \mathrm{NaCl}, 1 \mathrm{mM}$ EDTA, $1 \mathrm{mM}$ EGTA, $10 \mathrm{mM} \beta$-glycerophosphate, $10 \mathrm{mM} \mathrm{NaF}, 10 \mathrm{mM}$ pNPP, $0.4 \mathrm{mM}$ sodium orthovanadate, $1 \mathrm{mM}$ benzamidine, $2 \mathrm{mM}$ phenylmethylsulfonyl fluoride (PMSF), aprotinin, $1 \mathrm{mg} / \mathrm{ml}$ leupeptin, $1 \mathrm{mM}$ dithiothreitol (DTT) and 10\% Nonidet P-40). The cell lysate supernatant was collected by centrifugation and incubated with monoclonal anti-PI3K (p85) antibody (Cell Signaling, Beverly, MA) immobilized with protein G Sepharose (Sigma, St. Louis, MO) in immunoprecipitation buffer $(20 \mathrm{mM}$ Tris- $\mathrm{HCl}$ buffer $\mathrm{pH}$ 8.0, $500 \mathrm{mM} \mathrm{NaCl}, 1 \mathrm{mM}$ EDTA, $1 \mathrm{mM}$ EGTA, $10 \mathrm{mM}$ $\beta$-glycerophosphate, $10 \mathrm{mM} \mathrm{NaF}, 10 \mathrm{mM}$ pNPP, $0.4 \mathrm{mM}$ sodium orthovanadate, $1 \mathrm{mM}$ benzamidine, $2 \mathrm{mM}$ PMSF, $10 \mathrm{mg} / \mathrm{ml}$ aprotinin, $1 \mathrm{mg} / \mathrm{ml}$ leupeptin, $1 \mathrm{mM}$ DTT and $0.1 \%$ Nonidet P-40).

\section{Phospho-(Tyr) p85 PI3K Immunoblot}

PI3K (p85)-immunoprecipitated samples were separated by SDS-polyacrylamide gel electrophoresis (PAGE) and transferred to a polyvinylidene difluoride (PVDF) sheet. After blocking with $5 \%$ skim milk in Tris-buffered saline (TBS, $150 \mathrm{mM} \mathrm{NaCl}$ and $50 \mathrm{mM}$ Tris-HCl, $\mathrm{pH}$ 7.4), the sheet was incubated with monoclonal anti-PI3K (p85) (Cell Signaling) or rabbit polyclonal anti-phospho-(Tyr) p85 PI3K binding motif antibodies. The secondary antibody was horseradish peroxidase-conjugated sheep anti-mouse (Amersham, Piscataway, NJ) or donkey anti-rabbit IgG antibody (Amersham). The bound antibodies were visualized using the ECL system (Amersham), captured using Alliance 4.7 (UVItech, Ltd., Cambridge, UK) and quantified using UVIband software (UVItech, Ltd.).

\section{PI3K Activity Assay}

PI3K (p85)-immunoprecipitated samples were washed with serial solutions as follows, solution A: PBS containing $1 \%$ Nonidet P-40 and $1 \mathrm{mM}$ DTT, solution B: consisting of $0.1 \mathrm{M}$ Tris- $\mathrm{HCl}$ buffer ( $\mathrm{pH}$ 7.6), $0.5 \mathrm{M} \mathrm{LiCl}$ and $1 \mathrm{mM}$
DTT, and solution C: containing $10 \mathrm{mM}$ Tris- $\mathrm{HCl}$ buffer (pH 7.6), $0.1 \mathrm{M} \mathrm{NaCl}$ and $1 \mathrm{mM}$ DTT. This was followed by incubation with $0.5 \mathrm{mg} / \mathrm{ml}$ phosphoinositide fraction containing PtdIns(4,5)P2. Reaction buffer (50 mM MgCl2, $100 \mathrm{mM}$ HEPES buffer $\mathrm{pH}$ 7.6, $250 \mu \mathrm{M}$ ATP containing 5 $\mu \mathrm{Ci}$ of [32P]ATP) was added and incubated at $30^{\circ} \mathrm{C}$ for 10 min. Labelled-samples were then spotted on a thin layer chromatography (TLC) plate. The assay was continued as described by Chen et al. (12).

\section{Results}

Survivin induced tyrosine phosphorylation of p85 PI3K Similar levels of p85 PI3K were observed for all lanes (Figure 1), showing that the same volume of proteins were electrophorated and detected. Meanwhile, basal tyrosine phosphorylation of $\mathrm{p} 85$ PI3K (lane 1 from left) was seen in L929 cells. Upon infection of virus with vector only (lane 2 from left), the level of tyrosine phosphorylation of p85 PI3K in L929 cells was remained similar to the basal. However, upon infection of virus with survivin, a markedly increased level of tyrosine phosphorylation of p85 PI3K in L929 cells was seen (lane 3 from left). Low levels of tyrosine phosphorylation of p85 PI3K, even lower than the basal, were observed for Survivin-AS (lane 4 from left) and Survivin-S81A-viral-infected L929 cells (lane 5 from left).

IP: p85 PI3K

IB: phospho-(Tyr) p85 PI3K

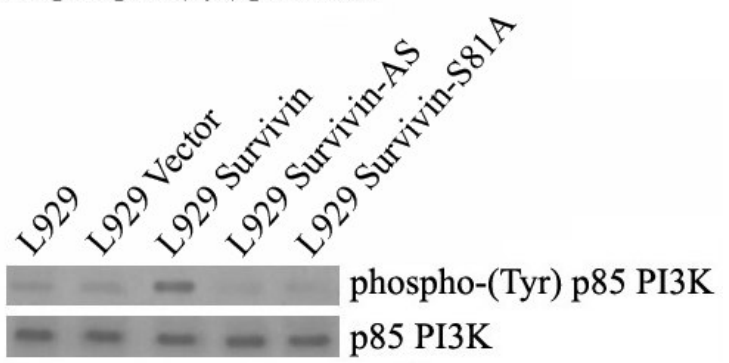

Figure 1. Survivin induced PI3K phosphorylation. L929 cells were infected with 200x107 viral particle/ml retrovirus of Survivin, Survivin-AS, Survivin-S81A or vector merely for 48 hours and cell sorted. Sorted cells were then lysed, immunoprecipitated using anti-p85 PI3K antibody and immunoblotted using anti-phospho(Tyr) p85 PI3K antibody. Detailed procedures were described in "Methods". This experiment was repeated 3 times.

\section{Survivin induced PI3K activity}

As shown in Figure 2, basal PtdIns(3,4,5)P3 (PIP3) smeary dot was seen (lane 1 from left). A clear PIP3 dot was seen for Survivin-viral-infected L929 cells (lane 3 from left). Meanwhile, smeary PIP3 dots were observed for Vector 
(lane 2 from left), Survivin-AS (lane 4 from left) and Survivin-S81A-viral-infected L929 cells (lane 5 from left).

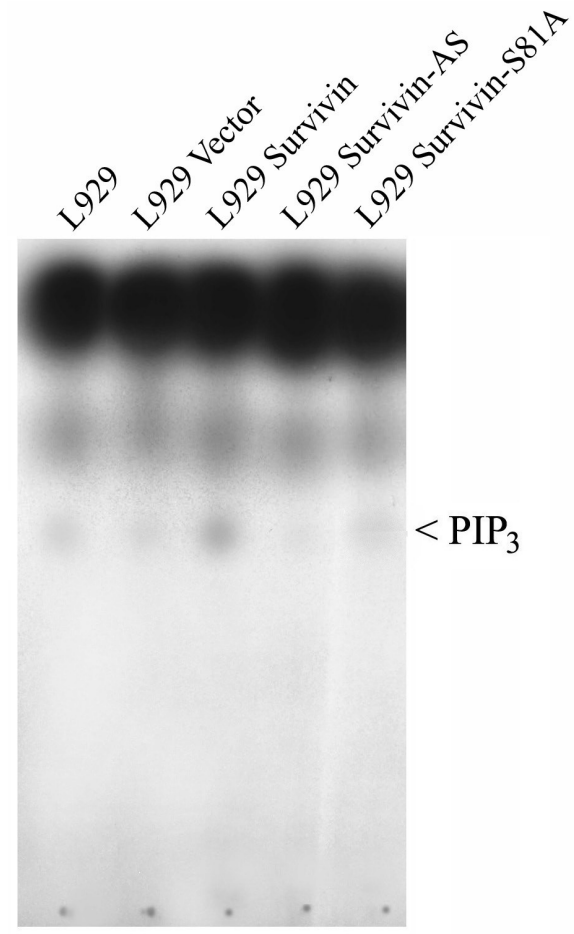

Figure 2. Survivin induced PI3K activity. L929 cells were infected with $200 \times 107$ viral particle/ml retrovirus of Survivin, Survivin-AS, Survivin-S81A or vector merely for 48 hours and cell sorted. Sorted cells were then lysed and subjected to PI3K activity assay. Detailed procedures were described in "Methods". This experiment was repeated 3 times.

\section{IP: p85 PI3K}

IB: phospho-(Tyr) p85 PI3K

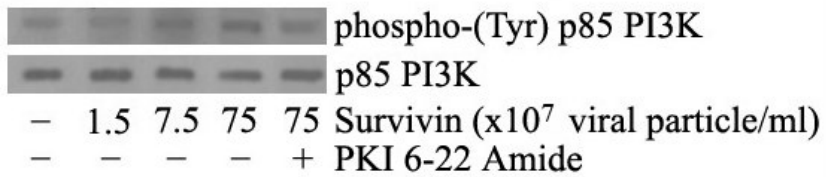

Figure 3. Survivin induced PI3K phosphorylation via PKA L929 cells were pretreated with/without $4 \mu \mathrm{M}$ PKI 6-22 amide for 2 hours prior to infection with different concentrations of Survivin retrovirus for 48 hours as indicated in the panel. Cell were sorted, lysed, immunoprecipitated using anti-p85 PI3K antibody and immunoblotted using anti-phospho-(Tyr) p85 PI3K antibody. Detailed procedures were described in "Methods". This experiment was repeated 3 times.

\section{PKI 6-22 amide inhibited Survivin-induced tyrosine} phosphorylation of p85 PI3K

To confirm same proteins were loaded, levels of p85 PI3K were observed. Yet, we found similar levels of p85 PI3K (Figure 3). Basal tyrosine phosphorylation of p85 PI3K (lane 1 from left) was seen in L929 cells. Upon infection of higher concentrations of virus with survivin, levels of tyrosine phosphorylation of p85 PI3K in L929 cells were gradually increased (lane 2-4 from left). A clear band of tyrosine phosphorylation of p85 PI3K was detected for $75 \times 107$ viral particle/ml Survivin-viral-infected L929 cells (lane 4 from left). However, when L929 cells were pretreated with $4 \mu \mathrm{M}$ PKI 6-22 amide, a synthetic peptide that acts as PKA inhibitor, prior to $75 \times 107$ viral particle/ml Survivinviral-infection, tyrosine phosphorylation level of p85 PI3K was detected much lower (lane 5 from left) compared to the one without PKI 6-22 amide pretreatment (lane 4 from left).

\section{PKI 6-22 amide inhibited Survivin-induced PI3K activity}

Basal PIP3 smeary dot was seen (Figure 4, lane 1 from left). Upon infection of higher concentrations of virus with survivin, levels of PIP3 dots were gradually clearly seen (lane 3-5 from left). A clear PIP3 dot was detected for $75 \times 107$ viral particle/ml Survivin-viral-infected L929 cells (lane 5 from left). However, when L929 cells were pretreated with $4 \mu \mathrm{M}$ PKI 6-22 amide, prior to $75 \times 107$ viral particle/ml Survivin-viral-infection, smeary PIP3 dot was resulted (lane 2 from left).

\section{Discussion}

Evidence for the existence of a positive feedback loop connecting survivin expression in tumor cells to PI3K/Akt was reported.(6) This signal enhanced $\beta$-catenin-Tcf/Lefdependent transcription followed by secretion of VEGF and angiogenesis.(6) In accordance, our current results had shown that Survivin could induce tyrosine phosphorylation of $\mathrm{p} 85 \mathrm{PI} 3 \mathrm{~K}$ and PI3K activation specifically. While Survivin induced tyrosine phosphorylation of p 85 PI3K and PI3K activity, Vector merely and Survivin-AS did not induce neither tyrosine phosphorylation of p85 PI3K nor PI3K activity. Based on our previous report, phosphorylation of Ser81 was crucial for activation of PKA.(10) In our current results, we found phosphorylation of Ser81 was also crucial in inducing tyrosine phosphorylation of $\mathrm{p} 85$ PI3K and activating PI3K. Survivin-PKA-PI3K signal pathway possibly play important role in anti-apoptosis/cytoprotection. In the opposite, Survivin-S81A-viral-infection was reported to enhance TRAIL's activity in inducing apoptosis.(7)

PKA was reported to have potential in regulating insulin receptor substrate-1 (IRS-1) and growth factor receptor bound protein 2-associated binding protein 2 (GAB2), adaptors that normally integrate receptor/ nonreceptor tyrosine kinase signaling into PI3K/Akt.(13) 


\section{Survivin \\ (x $10^{7}$ viral particle/ml) PKI 6-22 Amide

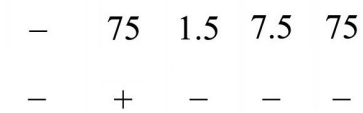

$\mathrm{PIP}_{3}>$
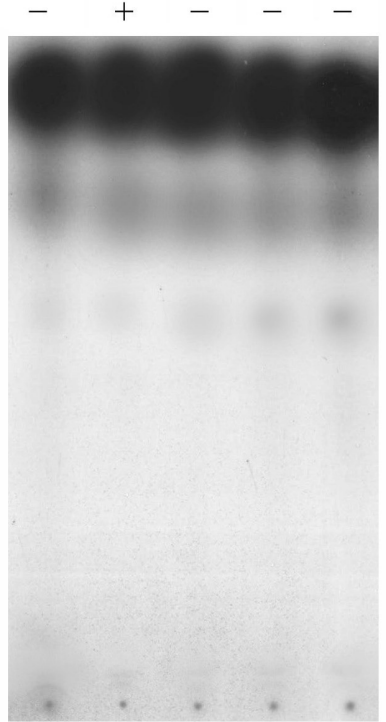

Figure 4. Survivin induced PI3K activity via PKA. L929 cells were pretreated with/without $4 \mu \mathrm{M}$ PKI 6-22 amide for 2 hours prior to infection with different concentrations of Survivin retrovirus for 48 hours as indicated in the panel. TNF- $\alpha$ was Cell were sorted, lysed and subjected to PI3K activity assay. Detailed procedures were described in "Methods". This experiment was repeated 3 times.

This reveals a new route for PKA to activate a pathway that promotes proliferation, inhibits apoptosis and enhances translation.(13) This report is in accordance with our previous report, showing that phosphorylated-Survivin at Ser81 induced PKA back loop.(10) In addition, our current results emphasized that Survivin-induced PI3K activation was mediated by PKA, since PKI 6-22 amide inhibited Survivin-induced pathway, as shown by lower tyrosine phosphorylation of p85 PI3K and PI3K activity upon pretreatment of PKI 6-22 amide prior to Survivin-viral infection.

Phosphatase and tensin homolog deleted on chromosome 10 (PTEN)/PI3K/Akt constitute an important pathway regulating the signaling of multiple biological processes such as apoptosis, metabolism, cell proliferation and cell growth.(14-17) PTEN is a non-redundant phosphatase, counteracting one of the most critical cancerpromoting pathways: the PI3K/Akt signaling pathway and its main substrate PIP3 is the product of PI3K.(14-19) Increase in PIP3 recruits Akt to the membrane where is activated by other kinases also dependent on PIP3.(14) Another positive feedback mechanism that decrease of E-cadherin, lowers PTEN and thereby increases PIP3, further activating Akt. (20) Many components of this pathway have been described as causal factors in cancer. $(14,15,17,18,20)$ Activation of PI3K and AKT are reported to occur in breast, ovarian, blood, pancreatic, esophageal, gallbladder and other cancers. $(14,17)$ Taken together, our current results suggest that Ser81 Survivin play an important role in inducing PI3K activation and the Survivin-PI3K signaling pathway was PKA-dependent. This provides important information to understand the mechanism induced by Survivin in mediating cytoprotection. However, further investigation to disclose downstream of Survivin-PKA-PI3K signaling pathway is necessary.

\section{Acknowledgement}

We thanks to Aristi Papaioannou from Department of Pathology, Harvard Medical School, for lab assistance.

\section{References}

1. Altieri DC. Targeting survivin in cancer. Cancer Lett. 2013; 332: 225 8.

2. Srinivasula SM, Ashwell JD. IAPs: what's in a name? Mol Cell. 2008; 30: $123-35$

3. Lens SM, Vader G, Medema RH. The case for Survivin as mitotic regulator. Curr Opin Cell Biol. 2006; 18: 616-22.

4. Paik S, Shak S, Tang G, Kim C, Baker J, Cronin M, et al. A multigene assay to predict recurrence of tamoxifen-treated, node-negative breast cancer. N Engl J Med. 2004; 351: 2817-26.

5. Cheung CH, Huang CC, Tsai FY, Lee JY, Cheng SM, Chang YC, et al. Survivin - biology and potential as a therapeutic target in oncology. Onco Targets Ther. 2013; 6: 1453-62.

6. Fernández JG, Rodríguez DA, Valenzuela M, Calderon C, Urzúa $\mathrm{U}$, Munroe $\mathrm{D}$, et al. Survivin expression promotes VEGFinduced tumor angiogenesis via PI3K/Akt enhanced $\beta$-catenin/ Tcf-Lef dependent transcription. Mol Cancer. 2014; 13: 209. doi: 10.1186/1476-4598-13-209.

7. Sandra F, Khosravi-Far R. Survivin S81A Enhanced TRAIL's Activity in Inducing Apoptosis. Indones Biomed J. 2010; 2: 113-7.

8. Kawamura K, Fukuda J, Shimizu Y, Kodama H, Tanaka T. Survivin contributes to the anti-apoptotic activities of transforming growth factor alpha in mouse blastocysts through phosphatidylinositol 3'-kinase pathway. Biol Reprod. 2005; 73: 1094-101.

9. O'Connor DS, Grossman D, Plescia J, Li F, Zhang H, Villa A, et al. Regulation of apoptosis at cell division by $\mathrm{p} 34 \mathrm{cdc} 2$ phosphorylation of survivin. Proc Natl Acad Sci USA. 2000; 97: 13103-7.

10. Sandra F, Khosravi-Far R. Phosphorylated-Survivin at Ser81 Induced Protein Kinase A (PKA): A back loop. Indones Biomed J. 2011; 3: 138-42.

11. Sousa LP, Lopes F, Silva DM, Tavares LP, Vieira AT, Rezende BM, et al. PDE4 inhibition drives resolution of neutrophilic inflammation by inducing apoptosis in a PKA-PI3K/Akt-dependent and NFkappaB-independent manner. J Leukoc Biol. 2010; 87: 895-904.

12. Chen N, Ma WY, Dong Z. Inositol hexaphosphate inhibits ultraviolet B-induced signal transduction. Mol Carcinog. 2001; 31: 139-44. 
13. Hunzicker-Dunn ME, Lopez-Biladeau B, Law NC, Fiedler SE, Carr DW, Maizels ET. PKA and GAB2 play central roles in the FSH signaling pathway to PI3K and AKT in ovarian granulosa cells. Proc Natl Acad Sci USA. 2012; 109: E2979-88. doi: 10.1073/ pnas. 1205661109.

14. Blanco-Aparicio C, Renner O, Leal JF, Carnero A. PTEN, more than the AKT pathway. Carcinogenesis. 2007; 28: 1379-86.

15. Zhang S, Yu D. PI(3)king apart PTEN's role in cancer. Clin Cancer Res. 2010; 16: 4325-30.

16. Newton AC, Trotman LC. Turning off AKT: PHLPP as a drug target. Annu Rev Pharmacol Toxicol. 2014; 54: 537-58.

17. Lunardi A, Webster KA, Papa A, Padmani B, Clohessy JG, Bronson $\mathrm{RT}$, et al. Role of aberrant PI3K pathway activation in gallbladder tumorigenesis. Oncotarget. 2014; 5: 894-900.

18. Carnero A, Paramio JM. The PTEN/PI3K/AKT Pathway in vivo, Cancer Mouse Models. Front Oncol. 2014; 4: 252. doi: 10.3389/ fonc.2014.00252.

19. Hawkins PT, Stephens LR. PI3K signalling in inflammation. Biochim Biophys Acta. 2014. pii: S1388-1981(14)00258-3. doi: 10.1016/j. bbalip.2014.12.006.

20. Qiao M, Sheng S, Pardee AB. Metastasis and AKT activation. Cell Cycle. 2008; 7: 2991-6. 